DOI 10.4467/2543733XSSB.17.036.8334

\author{
ELŻBIETA ZNAMIEROWSKA-RAKK
}

Uniwersytet Warszawski

\title{
BUŁGARZY CZY MACEDOŃCZYCY? WOKÓŁ SPISU LUDNOŚCI W MACEDONII PIRYŃSKIEJ Z GRUDNIA 1946 R.
}

Słowa kluczowe: Macedonia Piryńska, Ludowa Republika Macedonii, Moskwa, Belgrad, Skopie, Sofia, autonomia narodowo-kulturalna w Piryńskim Kraju, spis powszechny w Bułgarii w grudniu $1946 \mathrm{r}$.

W dyskursie naukowym dotyczącym problemu macedońskiego jedno z istotnych miejsc od wielu dziesiątków lat zajmuje spór o oblicze etniczne Macedonii Piryńskiej. Historiografia jugosłowiańska, a zwłaszcza ta wytworzona w Republice Macedonii (do i po 1991 r.) stawia kategorycznie tezę, że mieszkańcy Piryńskiego Kraju (Okręgu Gornodżumajskiego) byli i są narodowości macedońskiej. Na jej poparcie przytacza się wiele różnorakich argumentów, wśród których, w ocenie piśmiennictwa macedońskiego, bodaj największy ciężar gatunkowy mają wyniki spisu ludności, przeprowadzonego w Bułgarii w 1946 r. Pokazują one bowiem przewagę w Macedonii Piryńskiej tej części ludności, która optowała za przynależnością do narodowości macedońskiej. Mogłoby się wydawać, że skoro nawet same władze bułgarskie na podstawie przeprowadzonego spisu ogłosiły oficjalnie, iż większość mieszkańców Piryńskiego Kraju jest Macedończykami, stanowi to niezbity dowód macedońskiego oblicza etnicznego owego terytorium. Jednakże trzeba pamiętać, iż akcja spisowa z grudnia 1946 r. była nie tyle operacją statystyczną, pozwalającą na obiektywne ustalenie struktury narodowościowej Macedonii Piryńskiej, ile przede wszystkim przedsięwzięciem o charakterze politycznym, bynajmniej nieodzwierciedlającym rzeczywistego stanu rzeczy. Toteż, aby go poznać i właściwie zrozumieć, należy uwypuklić ówczesne realia wewnątrzpolityczne i międzynarodowe, w jakich przeprowadzono rejestrację populacji żyjącej w bułgarskiej części Macedonii w pierwszych latach po zakończeniu II wojny światowej.

A zatem, interpretując wyniki owego spisu przede wszystkim trzeba wziąć pod uwagę nader złożony kontekst historyczny tzw. kwestii macedońskiej, która zaistniała w XIX w. na Bałkanach podbitych przez Turcję osmańską. Pojawiła się w związku z przeciwstawnymi aspiracjami emancypujących się narodów bałkańskich, dążących do wyparcia Turków, 
zawładnięcia Macedonią i zasymilowania jej mieszkańców. W rezultacie na obszarze prowincji macedońskiej dochodziło do walki zbrojnej pomiędzy z jednej strony siłami osmańskimi, a z drugiej - Grekami, Bułgarami i Serbami, a zarazem do starć orężnych wśród nich samych. W tej kategorii konfliktów najostrzejszy był niewątpliwie antagonizm bułgarsko-grecki, co ujawniło się szczególnie silnie po utworzeniu Egzarchatu bułgarskiego w 1870 r. Wówczas Słowianie macedońscy, podlegli dotychczas w aspekcie wyznaniowym Patriarchatowi greckiemu, masowo porzucali jego jurysdykcję na rzecz nowo powstałego Kościoła narodowego Bułgarów. Z nim bowiem utożsamiali się głównie wskutek podobieństwa historycznego, etnicznego i językowego. Identyfikacji słowiańskich mieszkańców Macedonii z nacją bułgarską znacząco sprzyjał także niezwykle dynamiczny rozwój szkolnictwa podstawowego i zawodowego, które było tworzone i prowadzone na ziemiach macedońskich przez duchowieństwo bułgarskie. Ponadto pod koniec XIX w. nawiązana została współpraca polityczna i bojowa pomiędzy Wewnętrzną Macedońską Rewolucyjną Organizacją (WMRO), reprezentującą Słowian macedońskich, powstałą w Salonikach w 1893 r. z myślą o autonomii Macedonii, a Najwyższym Macedońskim Komitetem (WMK), utworzonym w 1895 r. na terytorium Księstwa Bułgarii, zmierzającego do przyłączenia prowincji macedońskiej do swych granic. W konsekwencji chociaż obie te organizacje prowadziły wspólne działania zbrojne przeciwko siłom Turcji osmańskiej, to jednak różniły je cele strategiczne. Niemniej intensywne kontakty osobiste, pomoc materialna i wojskowa WMK na rzecz WMRO zacieśniały relacje Słowian macedońskich z Bułgarami, co niewątpliwie miało także niebagatelny wpływ na utożsamianie się mieszkańców Macedonii z nacją bułgarską, pomimo braku jednoznacznej aprobaty liderów WMRO dla dążeń Księstwa Bułgarii do inkorporacji tego terytorium. Albowiem kluczowym punktem programu tej organizacji była autonomia Macedonii w ramach jakiejś szerszej struktury państwowej. Jednak aspiracji tych nie udało się zrealizować, a krwawo stłumione przez Turków największe powstanie macedońskie (Ilindeńsko-Preobrażeńskie) w 1903 r. osłabiło czasowo walki Słowian macedońskich o wolność i autonomiczny byt państwowy ${ }^{1}$.

Kolejny ważny etap w dziejach Macedonii zapoczątkowały wojny bałkańskie z lat 1912-1913, w rezultacie których prowincja ta wyzwolona została spod niewoli tureckiej, lecz uległa podziałowi pomiędzy Grecję (Macedonia Egejska), Serbię (Macedonia Wardarska) i Bułgarię (Macedonia Piryńska). Klęska Bułgarii w wojnie międzysojuszniczej spowodowała, że państwo to uzyskało najmniejszą część prowincji macedońskiej, a po I wojnie światowej część ta została jeszcze pomniejszona o Okręg Strumicy. Odcięcie tego obszaru oraz tzw. Kresów Zachodnich (Bosilegrad i Caribrod) od państwa bułgarskiego na rzecz państwa jugosłowiańskiego zaostrzyło dodatkowo ich wzajemne napięte stosunki. Wprawdzie przywódcy Bułgarii, pokonanej w I wojnie światowej i izolowanej na Bałkanach, usiłując poprawić swój wizerunek na arenie międzynarodowej dzięki polepszeniu relacji z Belgradem, taktycznie zawiesili swe pretensje do Macedonii, lecz nie wygasiło

\footnotetext{
1 Szerzej: E. Zn a m i e row s ka-R a k k, Działalność egzarchatu bułgarskiego na polu formowania świadomości narodowej Słowian macedońskich u schytku niewoli osmańskiej, [w:] Tożsamość narodowa w społeczeństwie multietnicznym Macedonii, red. M. Kawka, I. Stawowy-Kawka, Kraków 2008, s. 39-51; e a d e m, Rola duchowieństwa bułgarskiego $w$ rozwoju oświaty na ziemiach macedońskich na przełomie XIX $i$ XX wieku, [w:] Religia a polityka w Europie Środkowo-Wschodniej, red. I. Czamańska, W. Szulc, Poznań 2010; eadem, WMRO i NKMO na przetomie XIX i XX wieku. Sojusznicy czy rywale?, [w:] Macedoński dyskurs niepodległościowy. Historia-Kultura-Literatura-Język-Media, red. I. Stawowy-Kawka, M. Kawka, Kraków 2010.
} 
to ataków terrorystycznych, dokonywanych przez Macedończyków „wardarskich” we współpracy z Macedończykami „piryńskimi”, przeciwko władzom państwowym Jugosławii. A przy tym trzeba pamiętać, iż w relacjach bułgarsko-serbskich już w XIX w. miały miejsce konflikty, a także potyczki zbrojne na tle walki o dominację wpływów w Macedonii. Oliwy do ognia wrogości jugosłowiańsko-bułgarskiej z powodu sprzeczności w kwestii macedońskiej dolała bułgarska okupacja Macedonii Wardarskiej w czasie II wojny światowej na obszarze Królestwa Jugosławii, podbitego i rozczłonkowanego w 1941 r. przez III Rzeszę i jej sojuszników. Jednakże w końcowym etapie wojny, gdy powstała koniunktura polityczna sprzyjająca zbliżeniu powojennej Jugosławii, na czele z komunistycznym przywódcą Josipem Broz-Titą, z tzw. frontowoojczyźnianą Bułgarią, pozostającą pod faktyczną władzą Georgi Dymitrowa, kontrolowanego wszakże przez Stalina, pojawiła się szansa na ostateczne uregulowanie konfliktu o Macedonię. Szansa ta tkwiła w projekcie utworzenia wspólnego federacyjnego państwa, w ramach którego m.in. znalazłyby się połączone ziemie macedońskie. Macedonia Piryńska miała być włączona do Macedonii Wardarskiej, stanowiącej obszar Ludowej Republiki Macedonii (LRM) jako republiki związkowej Jugosławii. Tito, zadufany w sobie i przekonany o swoim autorytecie i silnej pozycji nie tylko w samej Jugosławii, ale również na arenie międzynarodowej, wśród przywódców mocarstw anglosaskich, zamierzał przyłączyć do LRM także Macedonię Egejską, należącą do Grecji, pomimo faktu, że w latach międzywojennych zatraciła ona w ogromnej mierze charakter słowiański. Niemniej jednak owych ambicji kierownictwu komunistycznej federacji Jugosławii z wielu przyczyn nie udało się zaspokoić. W tym stanie rzeczy Belgrad, podtrzymując zamysł unifikacji ziem macedońskich w granicach federacji jugosłowiańskiej, zdecydował o jak najszybszej bezpośredniej inkorporacji Macedonii Piryńskiej. Gdy jednak zamiar ten spalił na panewce, przywódcy jugosłowiańscy zainicjowali pilne negocjacje z władzami komunistycznymi Bułgarii w sprawie utworzenia Federacji Słowian Południowych. Wbrew oczekiwaniom strony jugosłowiańskiej na bezwarunkową akceptację przez Bułgarów projektu przedstawionego przez Belgrad, Sofia nie godziła się na proponowaną strukturę wspólnego państwa. Albowiem Jugosłowianie chcieli przyłączenia Bułgarii jako siódmej republiki, Bułgarzy natomiast upierali się przy układzie dualistycznym obu członów federacji. Kontrowersje pomiędzy negocjatorami dotyczyły też rozwiązania kwestii macedońskiej, ponieważ władze jugosłowiańskie starały się o cesję Macedonii Piryńskiej niekoniecznie po ukonstytuowaniu się państwa federacyjnego, a nawet bez związku z takim posunięciem, co było dla Bułgarów nie do przyjęcia. Całkiem wyraźnie taki zamysł kierownictwa jugosłowiańskiego uwidocznił się, gdy po zawieszeniu pertraktacji w sprawie utworzenia Federacji Słowian Południowych, zaistniała koniunktura niezwykle pomyślna dla planów Tity. Otóż w lecie 1946 r. relacje pomiędzy mocarstwami anglosaskimi a Związkiem Sowieckim coraz bardziej pogarszały się, a jeszcze wiele ważnych dla Moskwy spraw podlegało kompetencji konferencji pokojowej, na której przewagę miała strona anglosaska. Toteż Stalin, pragnąc na tym forum pozyskać poparcie Jugosławii dla swych interesów, wywarł presję na władze komunistyczne Bułgarii w duchu podporządkowania się forsowanej przez Titę idei nadania autonomii Macedonii Piryńskiej z perspektywą rychłego przyłączenia jej do LRM². Kierownictwo

${ }^{2}$ Makedonskiât v"pros v b"'lgaro-ŭgoslavskite otnošeniâ (1944-1952), Glavno Upravlenie na Arhivite pri Ministerskiâ S"vet na Republika B'"lgariâ, Sofiâ 2004 (MVBŬ), s. 81-82, 94-95; Centralen D"ržaven Arhiv (CDA), f. 1 b, op. 5, a. e. 6, 1. 131-137. 
bułgarskie zmuszone było przyjąć dyrektywę Kremla, ponieważ Bułgaria, w oczekiwaniu na podyktowanie jej warunków traktatu pokojowego, jako państwu przegranemu w wojnie, potrzebowała przychylności delegacji jugosłowiańskiej (a także delegacji sowieckiej) podczas obrad konferencji paryskiej. Jugosławia była także dla przywódców bułgarskich partnerem strategicznym $\mathrm{w}$ planach federacyjnych. Ponadto komuniści, dominujący w rządzie koalicyjnym w Bułgarii, mieli świadomość faktu, że są bezwzględnie zależni politycznie i gospodarczo od Moskwy, dzięki której zostali wyniesieni do pełni władzy w swym kraju, i mogli liczyć na pomoc sowiecką świadczoną w surowcach i kredytach. Toteż, ulegając naciskom dyktatora sowieckiego i przywódców jugosłowiańskich, w sierpniu 1946 r. na X Plenum KC BPR(k) bułgarskie władze komunistyczne przyjęły rezolucję w kwestii macedońskiej, zgodną z nakazem Stalina. Nie wchodząc w szczegóły owego dokumentu, należy stwierdzić, że jego treść, ogólnie biorąc, sprowadzała się do afirmacji istnienia narodu macedońskiego i uznania LRM za „prawdziwą ojczyznę” tej nacji i zarazem ogniwo jednoczące w najbliższej przyszłości Macedończyków „,wardarskich" i „piryńskich” w ramach titowskiej Jugosławii. Ponadto rezolucja podjęta na X Plenum nadawała Piryńskiemu Krajowi autonomię narodowo-kulturalną, ze wszystkimi implikacjami w sferze ideologii, propagandy, kultury, oświaty itp. ${ }^{3}$ Powyższe deklaracje i konkretne decyzje zmierzały do przygotowania mieszkańców Macedonii Piryńskiej do cesji owego terytorium na rzecz LRM w granicach komunistycznej federacji Jugosławii. Wprawdzie akt ten miał się dokonać na bazie wzajemnego sojuszu Bułgarii i Jugosławii, lecz $\mathrm{w}$ gruncie rzeczy pozostawało to $\mathrm{w}$ sferze mglistych i bliżej niesprecyzowanych czasowo projektów, jeśli nie wręcz pobożnych życzeń.

Rezolucja X Plenum KC BPR(k) wyznaczała cezurę nowego kursu w dotychczasowej chwiejnej polityce Sofii w kwestii macedońskiej. Kursu, który miał spowodować szybką i radykalną zmianę oblicza etnicznego bułgarskiej części Macedonii, wprowadzaną wszelkimi dostępnymi dla władz sposobami, nie wyłączając przymusu administracyjnego, a nawet represji, stosowanych przez reżymy totalitarne. Niemniej kierownictwo partii komunistycznej w okręgu gornodżumajskim (obejmującym obszar Macedonii Piryńskiej), dominujące we władzach tego regionu, przystępując do realizacji postanowień rezolucji, znalazło się w niezwykle skomplikowanej sytuacji. Z jednej bowiem strony zdawano sobie sprawę, że wdrożenie programu modyfikacji tożsamości narodowej mieszkańców Piryńskiego Kraju stanowiło priorytet w relacjach bułgarsko-jugosłowiańskich oraz pozostawało pod permanentną, czujną obserwacją Belgradu, Skopia, a także Moskwy, od których życzliwości i poparcia na paryskiej konferencji pokojowej i sesjach Rady Ministrów Spraw Zagranicznych wielkich mocarstw zależały przyszłe losy Bułgarii na arenie międzynarodowej. Od łaskawości Stalina zależała również pozycja komunistów bułgarskich wewnątrz kraju. Stąd dla komunistycznych władz Bułgarii zarówno na szczeblu centralnym, jak i regionalnym stało się jasne, że w zaistniałych realiach po X Plenum KC BPR(k) etap dotychczasowej taktyki kunktatorstwa, uników i meandrów w polityce Bułgarii wobec Macedonii Piryńskiej już minął i nadeszła pora odpowiedzialności za

${ }^{3}$ Szerzej na temat rezolucji X Plenum Komitetu Centralnego bułgarskiej partii komunistycznej oraz omawianego kontekstu politycznego zob. E. Z n a m i e r o w s k a-R a k k, Federacja Stowian poludniowych w polityce Butgarii po II wojnie światowej. Korzenie. Próby realizacji. Upadek, Warszawa 2005; MVBŬ, s. 90-91; CDA, f. 1 b, op. 5, a. e. $7,1.1-2$. 
skuteczne przekształcanie mieszkańców tego obszaru, w zdecydowanej większości identyfikujących się z nacją bułgarską, w „mniejszość macedońską”. Wszakże z drugiej strony, Komitet Okręgowy BPR(k) w Piryńskim Kraju nie mógł nie brać pod uwagę oporu wobec prowadzących do macedonizacji posunięć, przejawianego przez tamtejszych nie tylko mieszkańców, ale także przez masy partyjne własnej organizacji oraz członków partii demokratycznych, które początkowo pozostawały z komunistami w rządzie koalicyjnym Frontu Ojczyźnianego (FO), ale później przeszły do opozycji ${ }^{4}$. W tym stanie rzeczy macedonizacja owego terytorium jawiła się jako przedsięwzięcie niezwykle trudne, jeśli nie wręcz niemożliwe do szybkiego zrealizowania. Było wszak oczywiste, że Macedończycy „piryńscy” i osiedleni w innych częściach Bułgarii emigranci macedońscy w przeważającym stopniu utożsamiali się z Bułgarami. Za wszelką cenę pragnęli uniknąć przyłączenia do LRM, równoznacznego ze znalezieniem się w granicach państwa jugosłowiańskiego. Niezależnie bowiem od intensywnego „prania mózgów” przez bułgarską propagandę prokomunistycznych mediów, apologizującą ,przyjaźń, braterstwo i jedność” z narodami jugosłowiańskimi, w odczuciu tej ludności oznaczało to podporządkowanie „Serbom”, co przywoływało wspomnienia dotkliwego ucisku narodowościowego i ekonomicznego, jakiego dopuszczały się w międzywojniu władze królewskiej Jugosławii wobec Macedończyków „wardarskich”. Tego samego właśnie spodziewano się ze strony czynników rządzących w titowskiej Jugosławii, gdyby Macedończycy „piryńscy” trafili do LRM 5 .

Dodatkowym utrudnieniem w realizacji przyjętego przez X Plenum programu macedonizacji Macedończyków „,piryńskich” były trwające wówczas kampanie przed wrześniowym referendum w sprawie przekształcenia monarchicznego ustroju Bułgarii w republikę oraz przed październikowymi wyborami w tym kraju do Konstytuanty. Obawiano się bowiem, że natychmiastowe nagłośnienie decyzji kierownictwa partyjno-rządowego i ofensywne przystąpienie do działań w tak newralgicznej materii mogłoby się odbić niekorzystnie dla komunistów na wynikach wyborów. Toteż postanowiono utajnić treść rezolucji X Plenum przed społeczeństwem. Jednakże wieści o planowanej macedonizacji Piryńskiego Kraju docierały do jego mieszkańców przez prasę opozycyjną, a także pocztą pantoflową. Opozycja nie tylko ujawniała treść rezolucji X Plenum, ale również oskarżała rządzących o zdradę interesów narodowych i „sprzedanie Macedonii Piryńskiej Serbom”. Rezultaty tych działań z pewnością nie pozostawały bez wpływu na efekty podejmowanych w kierunku macedonizacji kroków. I tak np. obligatoryjny kolportaż prasy sprowadzanej z LRM, kino objazdowe, wyświetlające filmy w języku macedońskim (poddanym silnej serbizacji), ukazujące życie w LRM w różowych barwach, czy księgarnia objazdowa, wysłana do Piryńskiego Kraju przez władze skopijskie, nie cieszyły się większym zainteresowaniem ${ }^{6}$.

Jednym $\mathrm{z}$ fundamentalnych przedsięwzięć w procesie macedonizacji mieszkańców Macedonii Piryńskiej było nauczanie języka macedońskiego. Jednakże realizacja tego zadania okazała się w praktyce bardzo mało skuteczna. Zadecydowały o tym nie tylko braki kadry nauczycielskiej, ale przede wszystkim niechęć tamtejszej społeczności.

${ }^{4}$ CDA, f. 108, op. 1, a. e. 6, 1. 59-61; MVBŬ s. 108; „Svoboden Narod”, 19 XI 1946; „Narodno Zemedelsko Zname", 19 XI 1946.

5 „Zname”, 20 XII 1946, Ibidem, 24 XII 1946.

${ }^{6}$ CDA, f. 28, op. 1, a. e. 81, 1. 168-176; MVBŬ, s. 230, 236 i n. 
Jest rzeczą oczywistą, że używając na co dzień mowy bułgarskiej, miała ona duże opory przed perspektywą porzucenia tego języka, uważanego za ojczysty, na rzecz języka wprawdzie wyrosłego z analogicznego pnia lingwistycznego, lecz przecież obcego, bo w poważnej mierze zmodyfikowanego. Trzeba bowiem pamiętać, że język macedoński, po wprowadzeniu do niego z inicjatywy władz w Belgradzie, wielu zmian w zakresie słowotwórstwa, semantyki, frazeologii, reguł ortograficznych i gramatycznych, zbliżył się znacznie do języka serbskiego. Okoliczność ta budziła u większości Macedończyków „piryńskich” antyserbskie animozje i przywoływała nieprzyjemne asocjacje. W tym stanie rzeczy władze centralne i lokalne w Gornej Dżumai, a także w Skopiu, usiłowały przezwyciężyć przeszkody piętrzące się przed uczynieniem języka macedońskiego oficjalnym językiem urzędowym w Piryńskim Kraju. Kierownictwo LRM ufundowało 40 stypendiów dla nauczycieli z Macedonii Piryńskiej. Natomiast w samym Piryńskim Kraju, w miasteczkach i wsiach, organizowano dla pedagogów specjalistyczne kursy, przygotowujące ich do prowadzenia prelekcji o charakterze agitacyjnym i o tematyce skupionej wokół wpajania miejscowej ludności macedońskiej tożsamości oraz potrzeby podjęcia przez nią nauki języka macedońskiego. Równocześnie tworzono uniwersytety ludowe, gdzie podkreślano, iż mieszkańcy Macedonii Piryńskiej nie są Bułgarami, lecz należą do narodu macedońskiego. Toteż arbitralnie twierdzono, że Piryński Kraj jest regionem macedońskim, który powinien być jak najszybciej przyłączony do LRM. Szczególny nacisk w promowaniu macedońskości był położony na młode pokolenie, dla którego organizowano specjalne festiwale popularyzujące macedoński folklor w ubiorze, pieśni, poezji, prozie i sztukach teatralnych. Aranżowano także wzajemne wizyty studentów, uczniów, pionierów oraz innych grup dziecięcych i młodzieżowych. Wszakże trzeba przyznać, że rezultaty tych przedsięwzięć nie były zadowalające?

W odróżnieniu od serwilizmu bułgarskich czynników rządzących wobec władz w Belgradzie i w Skopiu, bułgarskie środowiska opozycyjne wypowiadały się radykalnie przeciwko macedonistycznym poczynaniom w Piryńskim Kraju i wzywały władze komunistyczne do położenia kresu wynaradawianiu ludności tego terytorium. Mieszkańcy Macedonii Piryńskiej, którzy - w ocenie przedstawicieli partii opozycyjnych - czuli się związani geograficznie, kulturowo i ekonomicznie z państwem bułgarskim, obawiali się formalnego oddzielenia od niego i odgórnego przyłączenia do titowskiej Jugosławii. Wszelako zarówno interpelacje zgłaszane w parlamencie przez opozycję, jak i apele prasy opozycyjnej pozostawały bez echa ${ }^{8}$. Należy podkreślić, że komuniści i opozycja w owym czasie w swej walce politycznej wykorzystywali kwestię macedońską, uznawaną powszechnie za niezwykle newralgiczną w świadomości historycznej narodu. Jednocześnie trzeba uwypuklić fakt, iż kierownictwo BPR(k) zbyt daleko już zaszło w propagowaniu

${ }^{7}$ B. Dzi ew iałtow s ki-G in tow t, Język jako argument $w$ dyskusji wokól kwestii macedońskiej $w$ XX wieku, [w:] Miejsce Macedonii na Bałkanach, red. I. Stawowy-Kawka, Kraków 2005, s. 137-142; MVBŬ, s. 96 i n.; B. Kon e sk i, The Macedonian Language, [w:] The Socialist Republic of Macedonia, Skopje 1974, s. 69-73; E. Ko fo s, Nationalism and Communism in Macedonia, Thessaloniki 1964, s. 160; L. P a n a o to v, K. P a lešutski, D. Mič ev, Makedonskiât v"pros i b"lgaro-ŭgoslavskite otnošeniâ, Sofiâ 1987, s. 108; por. N. D a vi e s, Europa. Rozprawa historyka z historia, Kraków 1998, s. 165.

${ }^{8}$ Okr"žen D"ržaven Arhiv - Blagoevgrad (ODA), f. 108, op. 1. a. e.14, 1. 423-443 za: V. An gelov, Hronika za edno nacjonalno predatelstvo. Opitite za nasilstveno denacionalizirane na Pirinska Makedoniâ (1944-1949), Blagoevgrad 1999, (V. Angelov, Hronika) s. 110; „Demokraciâ”, 8 III 1990; „Zora”, 24 VII 1990; „Svoboden Narod”, 19 XII 1946. 
macedonizmu i składaniu obietnic Belgradowi i Skopiu, żeby mogło sobie pozwolić na nawet najmniejszy odwrót od tego kursu, bez ryzyka dla projugosłowiańskiej orientacji w polityce zagranicznej Sofii, a tym samym utrzymania pomyślnego klimatu w relacjach z zachodnią sąsiadką. A zresztą opcja ta, zważywszy na ówczesną postawę Stalina - była dla rządzących komunistów bułgarskich w istocie bezalternatywna.

Toteż, aby zneutralizować oskarżenia opozycji, postanowiono przedstawić nowe argumenty, dowodzące niezbicie istnienia macedońskiej tożsamości narodowej u lwiej części mieszkańców Piryńskiego Kraju i emigracji macedońskiej, żyjącej w różnych innych regionach Bułgarii. Środkiem do osiągnięcia owego celu miał być powszechny spis ludności kraju, przeprowadzony do końca 1946 r. Władze partyjno-rządowe zakładały bowiem, że w rezultacie zastosowania odpowiedniej presji administracyjnej, ideologiczno-politycznej i psychologicznej wobec tej ludności wyzbędzie się ona swej bułgarskości i podczas spisu w okręgu gornodżumajskim opowie się za przynależnością do narodu macedońskiego. Tego rodzaju akcja wymagała od decydentów ogromnego wysiłku organizacyjnego w zmobilizowaniu wszelkich dostępnych sił ludzkich oraz środków materialnych. Należało bowiem stworzyć skuteczne mechanizmy wszechogarniającej propagandy i agitacji, zmierzających albo do pozyskania respondentów w celu zadeklarowania identyfikacji macedońskiej, albo - perswazji i zastraszania, zmuszających ich do porzucenia oporów i uległości wobec wymogów obowiązującej „,poprawności politycznej” pod groźbą zastosowania sankcji administracyjnych, politycznych, a nawet karnych. W praktyce dla mieszkańców Piryńskiego Kraju oznaczało to potencjalnie utratę pracy, piastowanego stanowiska, dobrej opinii w lokalnej społeczności, wysiedlenie, internowanie, a w skrajnych wypadkach - aresztowanie 9 .

Już na samym początku prac związanych z tworzeniem powiatowych i gminnych komisji spisowych pojawiły się duże trudności z naborem rachmistrzów, w dodatku uchylających się od uczestniczenia w specjalnych szkoleniach, jako że mieszkańcy Macedonii Piryńskiej postrzegali spis jako instrument służący planowanej cesji na rzecz LRM. W tej sytuacji władze okręgowe nakładały na wyznaczonych rachmistrzów grzywny lub kary aresztu. Ponadto organizowano specjalne komitety agitacyjne, które delegowały funkcyjnych i aktywistów partii komunistycznej oraz prorządowych instytucji do przeprowadzania odczytów i pogadanek w duchu macedonizmu, a także odwiedzania w domach ludności we wsiach i miasteczkach Piryńskiego Kraju, nalegając na pożądane wpisy w rubrykach spisowych ${ }^{10}$. Jednakże posunięcia te okazały się niewystarczające, co wzmogło obawy czynników rządzących, że operacja spisowa może okazać się niewypałem. Stąd też, aby nie dopuścić do takiego efektu, zdecydowano uciec się do wypróbowanych manipulacji, skrajnie niedemokratycznych metod, sprowadzających się do odgórnego, ręcznego sterowania czynnościami spisowymi. Przede wszystkim przyjęto założenie, że ludność Piryńskiego Kraju (jeśli głowa rodziny pochodziła z Macedonii Piryńskiej, to automatycznie wszystkich członków rodziny zapisywano jako Macedończyków), łącznie z Pomakami (zislamizowanymi Bułgarami), musi być pod względem narodowości kwalifikowana

9 ODA, f. 58, op. 1, a. e. 11, 31, 47, 56; ibidem, f. 61, op. 1, a. e. 36, 1. 192-192 za: D. Mičev, Makedonskiât v" pros i b"lgaro-ǔgoslavskite otnošeniâ (9 IX 1944-1949), Sofiâ 1994, s. 273; por. H. P o u 1 to n, Who are the Macedonians?, Bloomington and Indianapolis 1995, s. 160.

${ }_{10}$ ODA, f. 59, op. 1, a. e. 25, 1.89 i nn. za: W. Angelov, Hronika..., s. 125-126; D. Mičev, op. cit., s. $273-274$. 
jako macedońska, w co najmniej $70 \%{ }^{11}$. Co się zaś tyczy używanego języka, to ustalono, że mieszkańcy miast okręgu gornodżumajskiego mogą napisać w odpowiedniej rubryce, że mówią po bułgarsku, ale mieszkańcy wsi bez wyjątku byli zobowiązani oświadczyć, że ich ojczystym językiem jest macedoński ${ }^{12}$. Zatem władzom organizującym spis ludności w Piryńskim Kraju zależało nie na odzwierciedleniu rzeczywistego stanu rzeczy, lecz na formalnym udowodnieniu forsowanej tezy, że społeczność żyjąca na tym obszarze w zdecydowanej większości utożsamia się z nacją macedońską.

Główny ciężar przygotowań i przeprowadzenia czynności spisowych spoczął na strukturach kierowniczych okręgowego aparatu partyjnego i Frontu Ojczyźnianego (FO) w Gornej Dżumai, które traktowały spis nie tylko jako najważniejszą dyrektywę władz centralnych, ale także jako jeden z głównych frontów walki z opozycją. Toteż na wstępie towarzyszom partyjnym i ich współpracownikom rzucono hasło: „cała partia powinna być na nogach, aby pełną parą ruszyć do akcji mniej lub bardziej przymusowego uświadamiania Macedończykom «piryńskim», że należą do nacji macedońskiej”. W razie jednak pojawienia się u respondentów oporów czy wątpliwości co do takiej opcji, instrukcja Komitetu Okręgowego BPR(k) nakazywała użycie groźby zakwalifikowania ich do grona „faszystów” lub „wielkobułgarskich szowinistów”. W celu zaś rozwiania podejrzeń u spisywanej ludności, że optowanie za przynależnością do narodu macedońskiego spowoduje bezpośrednie odcięcie Piryńskiego Kraju od Bułgarii, centralne i lokalne czynniki rządzące ustami spolegliwych rachmistrzów skwapliwie zapewniały, że nic takiego nie nastąpi. Przeciwnie, twierdzono, że w wyniku pogłębienia zbliżenia bułgarsko-jugosłowiańskiego dojdzie do jeszcze bardziej ścisłego związku ludności «macedońskiej» z Bułgarami ${ }^{13}$. Manipulacja ta w niemałym stopniu kruszyła opory zarówno respondentów, jaki samych ankieterów spisowych. Ci ostatni, wypełniając odgórne dyrektywy ślepo, naiwnie lub z wyrachowania, trzymali się samousprawiedliwienia, że przez nakłanianie, zastraszanie, a także nadużycia w postaci „odpowiedniego wyręczania” osób starych, chorych, niepiśmiennych lub nieobecnych, czy też dokonywania „korektur” formularzy spisowych wypełnionych „niepoprawnie politycznie”, przyczyniają się do realizacji chlubnej idei południowosłowiańskiej federacji, łączącej Bułgarię z Jugosławią. Stąd też zapisywanie mieszkańców Macedonii Piryńskiej jako ludności macedońskiej było dla tych rachmistrzów zarówno wymogiem dyscypliny organizacyjnej lub służbowej, jak i swego rodzaju moralnym kompromisem, czynionym w imię ,konieczności ugruntowania jedności i solidarności Słowian południowych"14.

Jednakże trzeba stwierdzić, że bynajmniej nie wszyscy towarzysze partyjni i ich współpracownicy, włączeni do prac spisowych w Macedonii Piryńskiej, ulegali macedo-

${ }^{11}$ Okr"žen Partien Arhiv - Blagoevgrad (OPA), f. 7, op. 1, a. e. 2, 1. 119 za: D. M i č e v, op. cit., s. 274; V. Angelov, Akcâta za demografsko prebroâvane na naselenie v Pirinskiâ Kraj (25-31 dekemvri 1946 g.), „Istoričeski Pregled” [Sofiâ] 1990, br. 8, s. 51; por. R. L. Wolff, The Balkans in our Time, Cambridge, Mass. 1956, s. 318.

${ }^{12}$ OPA, f. 1, op. 1, a. e. 3, 1. 80-82 za: V. Angelov, Hronika ..., s. 127-128.

13 „Pirinsko Deło” 30 XII 1946; V. A n g e lov, Akcâta za demografsko prebroâvane..., s. 54-55.

${ }^{14}$ Np. sekretarz Komitetu Powiatowego BPR(k) w mieście Petrič przyznał, że „do X Plenum uważaliśmy się za Bułgarów. Potem jednak z powodu dyscypliny partyjnej pisaliśmy, że jesteśmy Macedończykami” OPA, f. 7, op. 1, a. e. 2, 1.118 za: V. Angelo v, Hronika..., s. 140; G. V. D i m it ro v, Za taka narečenata ,kulturna awtonomiâ" v Blagoevgradski okr”g (1946-1948), „Istoričeski Pregled”, [Sofiâ] 1979, br. 6, s. 74. 
nistycznym instrukcjom. Nie wszyscy też dawali się zwieść propagandzie, głoszącej, że wyrzeczenie się przynależności do narodu bułgarskiego stanowi ofiarę złożoną na ołtarzu przyjaźni i sojuszu Sofii z Belgradem. Albowiem, obok większości liderów i szeregowych członków partii, gotowych do bezwzględnego wpisywania w rubryce dotyczącej narodowości słowa „macedońska”, byli również tacy, którzy protestowali przeciwko obowiązkowi dyspozycyjności w uczestniczeniu w fałszerstwach spisowych. Wypadki te jednak dotyczyły głównie niższych instancji partyjnych, na szczeblu powiatów i gmin ${ }^{15}$. Znacznie częściej i w formie bardziej wyrazistej podobne sytuacje występowały w strukturach FO, lecz prawie wyłącznie wśród działaczy i członków partii demokratycznych współpracujących z komunistami. Natomiast otwartą walkę przeciwko metodom przymusu i groźby, stosowanym przez władze partyjno-państwowe, prowadziła opozycja. Prasa opozycyjna obnażała manipulacje czynników rządzących, które miały zapewnić ustalone apriorycznie rezultaty spisu. Wzywano do przeciwdziałania denacjonalizacji mieszkańców Piryńskiego Kraju przez eksponowanie ich narodowości bułgarskiej i bojkot imprez promujących kulturę macedońską ${ }^{16}$. W reakcji na krytykę opozycji prorządowe dzienniki „Rabotničesko Delo”, „Pirinsko Delo” i „Makedonsko Zname” wystąpiły z ostrymi atakami zmierzającymi do całkowitej jej dyskredytacji. Krytykom akcji spisowej w Macedonii Piryńskiej stawiano zarzuty, że opozycja „dzieli naród”, „mąci demokratyczny porządek i praworządność”, „uprawia szpiegostwo na rzecz greckich monarchofaszystów” oraz „powoduje się wielkobułgarskim szowinizmem”. Jednocześnie media dyspozycyjne wobec władz przekonywały społeczeństwo, że macedonizacja ludności Piryńskiego Kraju jest w pełni uzasadniona „historycznie, logicznie i żywotnymi interesami nie tylko Macedończyków, ale również samych Bułgarów"17.

W konsekwencji wszystkich tych posunięć spis ludności przeprowadzony w Macedonii Piryńskiej w końcu grudnia 1946 r., ogólnie biorąc, okazał się przedsięwzięciem odpowiadającym oczekiwaniom władz. Uzyskane bowiem wyniki pokazują, że na 252575 mieszkańców okręgu gornodżumajskiego 160 641, czyli 63,6\%, optowało za narodowością macedońską, a jako „Bułgarzy” określiło się 54425 osób, co stanowiło 21,5\%; z kolei narodowość pomacką zadeklarowały 28924 osoby, czyli 11,5\% ${ }^{18}$.

Analizując powyższe dane, historyk bułgarski Weselin Angełow, specjalizujący się w badaniu dziejów najnowszych Piryńskiego Kraju, zwraca uwagę na fakt, że spośród tych, którzy wskazali, że są narodowości macedońskiej, aż 131954 osoby, czyli ponad $82 \%$, jednocześnie podały, iż ich językiem macierzystym jest bułgarski. Jedynie 28611 respondentów zadeklarowało, że takim językiem jest dla nich macedoński. Okoliczność ta - zdaniem owego badacza - nadaje rezultatom spisu wymowę rzucającą cień na propagandową euforię zwolenników macedonizmu ${ }^{19}$. W zasadzie można by zgodzić się z poglądem, że wykładnia danych liczbowych, przeprowadzona z punktu widzenia używanej mowy ojczystej przez mieszkańców Macedonii Piryńskiej, świadczy raczej o ich

\footnotetext{
15 OPA, f. 1, op. 1, a. e. 8, 1. 6 za: V. Angelov, Hronika..., s. 136-138; „Pirinsko Delo” 6 I 1947.

16 „Svoboden Narod”, 20 X 1946, 29 XII 1946, 12 I 1947; „Zname” 19 XI 1946, „Narodno Zemedelsko Zname", 3 I 1947.

17 „Pirinsko Delo”, 6 I 1947; Stenografski dnevnici na Velikoto Narodno S”brnie, č I, 1946-1949, 10 zasedanie, Sofiâ 3 XII 1946, s. 87.

18 MVBŬ, s. 154-155.

19 V. Angelov, Hronika..., s. 143.
} 
przynależności do narodu bułgarskiego. Niemniej trzeba przyznać, że o wiele bardziej przekonywałyby o tym inne racje. Albowiem język ojczysty nie jest ani jedyną, ani najpewniejszą cechą pochodzenia i przynależności do danego narodu. Stąd w badaniach statystycznych dotyczących tożsamości etnicznej częściej za bardziej miarodajne uznaje się kryteria subiektywne, kładące nacisk nie na takie kategorie, jak: język ojczysty, obyczaje, zwyczaje czy wyznawana wiara, lecz na poczucie własnej identyfikacji narodowej wyrażone explicite przez respondentów. Toteż zwolennicy doktryny macedonizmu posługiwali się argumentem, że spisywana ludność Piryńskiego Kraju dowiodła swej macedońskości przez „osobiste, bezpośrednie wskazanie na przynależność do narodu macedońskiego”. Ale należy podkreślić, iż owo „samookreślenie” tylko z nazwy miało charakter swobodnego zadeklarowania swego poczucia narodowego. Faktycznie bowiem było ono przeprowadzone mocą odgórnych decyzji gabinetowych, zarządzeń administracyjnych, nie wyłączając presji psychologicznej i fałszerstw, dlatego nie stanowiło odbicia autentycznego obrazu identyfikacji narodowej Macedończyków „piryńskich”.

Nie przeszkadzało to wszakże stronie jugosłowiańskiej prezentować wyników spisu w Macedonii Piryńskiej jako triumfu polityki macedonizmu i zarazem tytułu do twierdzenia, że na tym obszarze żyje mniejszość macedońska. To zaś - w opinii kierownictwa belgradzkiego i skopijskiego - uprawniało do głoszenia o konieczności dokonania cesji bułgarskiej części Macedonii na rzecz LRM, pod szyldem realizacji idei ,zjednoczenia narodu macedońskiego". Zatem o ile rezultaty akcji spisowej w Piryńskim Kraju były, po odrzuceniu polityki macedonizmu ok. 1956 r., w dalszych latach utajnione, o tyle w LRM były one i są nadal intensywnie nagłaśniane i rozpowszechniane, aby uzasadnić roszczenia pod adresem Bułgarii, wysuwane w „obronie praw mniejszości macedońskiej”, żyjącej w granicach tego państwa ${ }^{20}$.

Spis ludności stanowił niejako zwieńczenie pierwszego etapu macedonizacji Piryńskiego Kraju. Toteż w ocenie bułgarskich władz partyjno-rządowych narzucała się potrzeba podsumowania efektów dotychczasowych różnorakich przedsięwzięć macedonistycznych oraz wytyczenia dalszych kierunków realizacji polityki macedonizmu. W tym celu na początku stycznia 1947 r. odbyto naradę KC BPR(k) z udziałem przedstawicieli kierownictw partii i FO w okręgu gornodżumajskim. Zebraniu przewodniczył Wyłko Czerwenkow, jako odpowiedzialny w Biurze Politycznym za sprawy macedońskie, zamiast dotychczas pełniącego tę funkcję Władimira Poptomowa, który utracił zaufanie strony jugosłowiańskiej z powodu ,nazbyt probułgarskiej pozycji”. Niemniej, jako członek tego gremium, uczestniczył on w naradzie wraz z Dymitrem Ganewem, reprezentującym podobne stanowisko w kwestii macedońskiej.

W referacie wprowadzającym Czerwenkow skupił się na konieczności dalszego wdrażania w życie rezolucji X Plenum. Konkretnie wnioskował o zamieszczenie w przyszłej konstytucji Bułgarii zapisu dotyczącego autonomii kulturalnej dla mieszkańców Piryńskiego Kraju, a w jej ramach - nauczania języka macedońskiego, historii macedońskiej, otwarcia macedońskich księgarni i rozwijania wszechstronnych więzi z LRM ${ }^{21}$. Tymczasem podczas dyskusji stwierdzono, że pomimo usilnych starań macedonizacyjnych,

${ }^{20}$ H. P o u l to n, Who are the Macedonians, s. 148; V. J o te v s k i, Nacionalnata afirmacja na Macedoncite vo Pirinskot del na Makedonija 1944-1948, Skopje 1996, s. 105-112; Dokumenti za borbata na makedonskiot narod za samostojnost $i$ za nacionalna država, t. I, Skopje 1981, s. 682.

${ }^{21}$ CPA, f. 146, op. 5, a. e. 24, 1. 8-23; L. Panajotov, K. Palešutski, D. Mičev, op. cit., s. 108-109. 
rezultaty były raczej mizerne, głównie wskutek oporu ludności Macedonii Piryńskiej. Z wypowiedzi uczestników narady, wywodzących się z aktywu partyjnego i frontowo-ojczyźnianego, wynikało, że mieszkańcy tego terytorium w większości nie wykazywali chęci uczenia się języka macedońskiego ani zgłębiania dziejów ,walki narodowowyzwoleńczej narodu macedońskiego". Zdecydowanie też nie życzyli sobie przyłączenia do LRM, gdyż obawiali się zwierzchności władz titowskiej Jugosławii. Ponadto zgłaszano poważne zastrzeżenia co do metod przymuszania respondentów podczas akcji spisowej do podawania narodowości macedońskiej. Naturalnie te głosy krytyczne ze strony niektórych dyskutantów były wyciszane lub podważane w imię ,poprawności politycznej”"22.

Jednakże pomimo atmosfery niesprzyjającej rzetelnej wymianie myśli w trakcie dyskusji doszło do zaprezentowania dwóch zdecydowanie krytycznych ocen macedonistycznej linii partii. Pierwsza wypowiedź należała do wspomnianego wyżej Poptomowa, który przede wszystkim uwypuklił potrzebę łącznego traktowania cesji Macedonii Piryńskiej na rzecz LRM z kwestią projektowanej federacji Słowian południowych. W tym kontekście postawił zarzut niektórym działaczom partii i FO w okręgu gornodżumajskim, że „więcej mówią o połączeniu obu słowiańskich części Macedonii aniżeli o unii południowosłowiańskiej”. Ponadto podkreślił nadużycia, jakich dopuszczały się lokalne władze partyjne w czasie przeprowadzania spisu ludności ${ }^{23}$. Drugim mówcą kwestionującym, i to o wiele ostrzej, kurs macedonizmu partii i rządu był Dymitr Ganew. Głównie skoncentrował się on na krytyce uległości i serwilizmu wobec Skopia ze strony przywódców lokalnych struktur BPR(k) i FO w Macedonii Piryńskiej. Piętnując tego rodzaju postawy, stwierdził, że wsłuchują się oni w oczekiwania kierownictwa skopijskiego i forsują kwestię przyłączenia Piryńskiego Kraju do LRM jako oręż w walce przeciwko „wielkobułgarskiemu szowinizmowi”, co faktycznie oznacza walkę z Bułgarią, bułgarską partią komunistyczną i narodem bułgarskim. Ostrzegał też, że nieuwzględnienie faktu, iż w Macedonii Piryńskiej obok Macedończyków mieszkają również Bułgarzy może grozić wygenerowaniem zjawiska szowinizmu ,wielkomacedońskiego”. W konkluzji swych wywodów Ganew oświadczył, że w okręgu gornodżumajskim obowiązuje posłuszeństwo władzom bułgarskim, a nie przywódcom skopijskim, gdyż nie może być tam dwuwładzy ${ }^{24}$.

Wystąpienia obu członków Biura Politycznego, stanowczo kontestujące macedonistyczną linię partii, rozpłynęły się wszakże w powodzi słów tych uczestników narady, którzy kategorycznie opowiadali się za kontynuacją prowadzonego kursu. Stąd też, pomimo konkretnych zarzutów pod adresem inspiratorów i wykonawców programu macedonizacji Piryńskiego Kraju, bez trudu przegłosowano wniosek dotyczący wzmożenia wysiłków w kierunku pełnego urzeczywistnienia założeń autonomii narodowo-kulturalnej ludności tego obszaru. W szczególności zadecydowano o wprowadzeniu do szkół obowiązku nauczania języka macedońskiego i historii Macedonii, otwieraniu kolejnych księgarni macedońskich, wysyłaniu dzieci i młodzieży na naukę do Skopia oraz innych przedsięwzięciach mających na celu wszczepienie młodemu pokoleniu macedońskiej świadomości narodowej, natomiast dorosłym - przekształcenie bułgarskiej tożsamości w identyfikację macedońską ${ }^{25}$.

${ }^{22}$ CPA, f. 146, op. 5, a. e. 24, 1. 8-23; N. Velj a nov s k i, Makedonija vo jugoslovensko-bugarskite odnosi (1944-1953), Skopje 1998, s. 183-185.

${ }^{23}$ CPA, f. 146 , op. 5 , a. e. $24,1.18$.

24 Ibidem, 1. 19-22.

25 D. Mičev, op. cit., s. 289. 
Niemniej trzeba zauważyć, że choć krytyczne wypowiedzi Poptomowa i Ganewa nie spowodowały zasadniczych zmian w formule wszechogarniającej macedonizacji okręgu gornodżumajskiego, to jednak stanowiły one pewien czynnik hamujący proces jej realizacji. Najwidoczniej wyraziło się to w odstąpieniu kierownictwa partyjnego od włączenia do konstytucji zapisu stwierdzającego, że Macedonia Piryńska jest „,macedońskim krajem narodowym w granicach Bułgarii”. W dalszych miesiącach po styczniowej naradzie nasiliła się tendencja do czasowego odłożenia niektórych decyzji dotyczących autonomii narodowo-kulturalnej. A zatem pewien wpływ na spowolnienie tempa macedonizacji tego terytorium miały pogłębiające się różnice w kwestii macedońskiej wśród członków BP KC BPR(k). Najbardziej zdecydowanym oponentem polityki macedonizmu w tym gremium był Władimir Poptomow, który w połowie stycznia 1947 r. podjął kolejną próbę powstrzymania posunięć macedonizacyjnych, przynajmniej w części Piryńskiego Kraju ${ }^{26}$. Akcję tę wzmocniły protesty wyrażane na wielką skalę przez opozycję, skonsolidowaną wewnątrz i na zewnątrz Wielkiego Zgromadzenia Narodowego. W rezultacie w ciągu następnych miesięcy w okręgu gornodżumajskim osłabło tempo macedonizacji. Czynniki rządzące obawiały się, że z powodu swej wasalnej postawy wobec Belgradu i Skopia zostaną potępione i skompromitowane w oczach własnego społeczeństwa i opinii międzynarodowej. Toteż do czasu ostatecznego rozbicia sił opozycyjnych uznano za konieczne ograniczenie programu intensywnej macedonizacji tego okręgu.

Jeszcze inną przeszkodą, która skutecznie utrudniała wdrażanie autonomii w Piryńskim Kraju, był sprzeciw wobec polityki macedonizmu ze strony przeważającej części emigracji macedońskiej, zamieszkałej w Bułgarii poza Macedonią Piryńską. Środowiska tych emigrantów, identyfikujących się narodowo z Bułgarami, oceniały macedonistyczne posunięcia władz jednoznacznie negatywnie jako działania naruszające rację stanu państwa bułgarskiego, z którym się utożsamiały. Warto zwrócić uwagę, że stanowisko takie bardzo wyraźnie odzwierciedliły rezultaty spisu ludności w Bułgarii z końca 1946 r., które wykazały, że na około 600000 emigrantów macedońskich jedynie 14,8\% zadeklarowało swą przynależność do narodu macedońskiego ${ }^{27}$. Postawa tej emigracji, rzecz oczywista, nie pozostawała bez wpływu na opór mieszkańców Piryńskiego Kraju wobec przymusowej macedonizacji. Toteż czynniki rządzące, zresztą zainspirowane i ponaglane przez Belgrad i Skopie, zdecydowały się definitywnie zlikwidować struktury przywódcze emigracji macedońskiej. W akcji tej szczególnie brano pod uwagę Bractwa Macedońskie, Organizację Ilindeńską oraz Macedoński Instytut Naukowy (MNI) w Sofii, które prowadziły najbardziej aktywną działalność, ostro kontestującą politykę władz w kwestii macedońskiej. W dążeniu do zdyskredytowania MNI propaganda partyjno-rządowa, podążając za jugosłowiańskimi wytycznymi, podkreślała, że stał się on „,rozsadnikiem dzikiego szowinizmu”, że „sprzyjał faszystowskim okupantom”, ,siał wrogie uczucia do bratnich narodów jugosłowiańskich oraz „,wielkobułgarski szowinizm”, tudzież „,negował istnienie narodu macedońskiego". Za pomocą analogicznych oskarżeń usiłowano także zdezawuować Bractwa Macedońskie i Organizację Ilindeńską. Do podjęcia decyzji o rozwiązaniu

${ }^{26}$ CPA, f. 146, op. 5, a. e. 298, 1. 3-5; ibidem, f. 1, op. 6, a. e. 527, 1. 5-22; BKP, Komintern"t i Makedonskiât v"pros (1917-1946), Glavno Upravlenie na Arhivite pri Ministerskiâ S"vet na Republika B"'lgariâ, t. II, Sofiâ 1999, s. 1206-1221.

27 V. Angelov, Hronika..., s. 143. 
obu tych organizacji i zamknięciu ich organów prasowych oraz przeniesieniu MNI do Skopia doszło 5 marca 1947 r. na mocy uchwały BP KC BPR(k $)^{28}$. Powstała wskutek tego próżnia miała być zagospodarowana nowymi „odpowiednimi” strukturami - Macedońskimi Towarzystwami Kulturalno-Oświatowymi, jako organizacjami mniejszości narodowej, kierowanymi przez aktywistów podporządkowanych władzom bułgarskim oraz spolegliwych wobec Skopia. Zatem działalność statutowa owych tworów sprowadzałaby się $\mathrm{w}$ istocie do infiltrowania różnych środowisk emigracji macedońskiej w Bułgarii, w duchu wszczepiania im macedońskiej świadomości narodowej oraz integrowania z mieszkańcami Piryńskiego Kraju pod hasłem zbliżenia i jedności z LRM w celu jak najszybszej fuzji obu słowiańskich części Macedoniii ${ }^{29}$.

Posunięcia likwidacyjne władz partyjno-rządowych wywołały niezadowolenie środowisk emigracji macedońskiej i mieszkańców Piryńskiego Kraju. Szczególnie ostre protesty spowodowała decyzja o przeniesieniu MNI do LRM. Wskazując na znaczące zasługi tej placówki „w obronie interesów narodowych Bułgarii przeciwko fałszerstwom uczonych serbskich i greckich", wiele znanych osobistości ze świata bułgarskiej nauki i kultury, związanych z działalnością MNI, usiłowało wpłynąć na zmianę w tym względzie stanowiska czynników rządzących. Wszakże wysiłki te okazały się bezowocne, ponieważ komunistyczna partia i rząd w Bułgarii zbyt daleko już zaszły w utożsamianiu się z doktryną macedonizmu ${ }^{30}$.

Równolegle z poczynaniami zmierzającymi do rozwiązania organizacji i instytucji emigracji macedońskiej w Bułgarii, na początku 1947 r. nasiliła się ofensywa we wdrażaniu autonomii narodowo-kulturalnej w Piryńskim Kraju. Akcja ta była nader bacznie monitorowana przez kierownictwo polityczne w Belgradzie i w Skopiu. Trzeba bowiem pamiętać, że w planach jugosłowiańskich ludność okręgu gornodżumajskiego miała rychło stać się obywatelami LRM w odróżnieniu od emigrantów macedońskich, zamieszkałych w innych rejonach Bułgarii. W związku z tym byli oni przez Jugosłowian przewidywani głównie jako ewentualny czynnik wspierający ich macedonistyczne cele wobec Macedończyków „piryńskich”.

Wśród przyjętych kierunków macedonizacji ludności Piryńskiego Kraju, po analizie przyczyn słabych wyników tego procesu uzyskanych do końca 1946 r., za podstawowy, warunkujący jego skuteczność, uznano wzmożenie pracy wyjaśniającej i popularyzatorskiej, dotyczącej takich zagadnień jak: istnienie nacji macedońskiej, powstanie LRM jako pierwszego państwa Macedończyków i jego rola w zjednoczeniu narodu macedońskiego oraz połączenie obu słowiańskich części Macedonii. Dopiero potem zamierzano przystąpić do nauczania języka i historii Macedonii - fundamentalnych instrumentów wszczepiania macedońskiej świadomości narodowej. Realizując hasło rzucone przez okręgowe władze partyjne i FO w Gornej Dżumai: „,rok 1947 rokiem ostatecznego zmacedonizowania Piryńskiego Kraju", organizacje partyjne na szczeblu powiatów i gmin, pozostając pod obstrzałem krytyki BP KC BPR(k) i osobiście Wyłki Czerwenkowa, przyjęły rezolucję o zintensyfikowaniu implementacji postanowień X Plenum, uznanych wszak za bezdy-

${ }^{28}$ CPA, f. 146, op. 4, a. e. 1148, 1. 1-2; ibidem, f. 1, op. 15, a. e. 221, 1. 1-7; L. Panajotov, K. Palešutski, D. Mičev, op. cit., s. 109; D. Mičev, op. cit., s. 292-293.

${ }^{29}$ CDA RB, f. 28, op. 1, a. e. 117, 1. 18-19.

${ }^{30}$ CPA, f. 147, op. 3, a. e. 954, 1. 1; ibidem, f. 214, op. 1, a. e. 462, 1. 1-6; V. An g elov, Hronika..., s. 157. 
skusyjne dyrektywy ${ }^{31}$. Implikowało to również presję na tzw. partie sojusznicze, komitety FO, które pomimo pewnej generalnej rezerwy wobec linii macedonistycznej, jednak ją realizowały. Zwłaszcza $\mathrm{w}$ tych wszystkich działaniach, które miały bezpośrednio pogłębiać „braterskie uczucia między mieszkańcami Piryńskiego Kraju a ludnością LRM”. Wyraziło się to m.in. w zwiększeniu częstotliwości wymiany delegacji, reprezentujących różne środowiska społeczne, gospodarcze i kulturalne, w organizowaniu uroczystości rocznicowych i świątecznych, czy wzajemnym popularyzowaniu dorobku kulturalnego.

Znaczącą rolę w tej ostatniej dziedzinie odgrywała księgarnia macedońska otwarta w Gornej Dżumai, która w szybkim czasie stała się sztandarową instytucją LRM na obszarze Macedonii Piryńskiej, formującą i szerzącą postawy macedońskiej identyfikacji narodowej. Zarazem placówka ta pełniła funkcję swoistego sztabu koordynacyjnego dla emisariuszy przybywających ze Skopia w celu kompleksowego przygotowywania warunków, na jakich Macedonia Piryńska miała być przyłączona do Macedonii Wardarskiej. Warto dodać, że w ślad za otwarciem pierwszej księgarni macedońskiej w głównym mieście okręgu gornodżumajskiego w niedługim czasie we wszystkich miastach powiatowych Piryńskiego Kraju miały powstać kolejne tego typu ośrodki krzewiące macedonizm. Jednakże rychło okazało się, że oczekiwane sukcesy tych księgarni w sferze zaszczepiania macedońskiej świadomości narodowej były iluzją. Poza bowiem funkcjonariuszami i częściowo szeregowymi członkami BPR(k) mało kto interesował się literaturą czy prasą sprowadzaną z LRM, a sale, w których organizowano filomacedońskie odczyty i pogadanki, często świeciły pustkami. Toteż dla stworzenia przynajmniej pozorów, że istnieje zapotrzebowanie na funkcjonowanie tych placówek, mocą dyrektywy gornodżumajskiego Komitetu Okręgowego BPR(k) i Komitetu Naczelnego FO na podległe im organizacje szczebla powiatowego i gminnego nałożono obowiązek abonamentu na zakup gazet i książek macedońskich ${ }^{32}$.

Trzeba stwierdzić, że również pozostałe instrumenty, wykorzystywane przez władze do totalnego zmacedonizowania ludności Piryńskiego Kraju, nie przyniosły spodziewanych efektów. Podczas zebrań okręgowych, powiatowych i gminnych instancji partii i FO niezmiennie konstatowano z zatroskaniem, że pomimo intensywnych wielokierunkowych zabiegów, ich wyniki ciągle są niezadowalające. Przyznawano bez ogródek, że generalnie zainteresowanie piśmiennictwem i prasą macedońską jest słabe, głównie z powodu nieznajomości języka macedońskiego; a w tym aspekcie sprawy także nie przedstawiały się optymistycznie. Przytaczano opinie poszczególnych osób, wywodzących się zarówno z grona nauczycieli, jak i uczniów (dzieci, młodzieży i dorosłych), którzy twierdzili zgodnie, że nie widzą potrzeby znajomości jezyka macedońskiego jako sztucznego tworu językowego, nasyconego serbizmami, co dodatkowo wywoływało nieprzyjemne asocjacje polityczne. Stąd też argumenty te brzmiały dość przekonująco, tym bardziej że brak motywacji do nauki prowadził do zaniedbań w systematycznej edukacji, częstej zmiany edukatorów, a nierzadko nawet do całkowitej rezygnacji zarówno z pobierania nauki, jak i nauczania. Podobnie też nie zauważano u tamtejszej ludności większego zaciekawienia historią Macedonii, co wynikało nie tylko z nieznajomości języka, ale prawdopodobnie

31 CPA, f. 147, op. 1, a. e. 1004, 1. 75-78; „Makedonsko Zname” 1 I 1947; „Pirinsko Delo” 24 III 1947.

${ }^{32}$ CPA, f. 146, op. 5, a. e. 298, 1. 7-9; ibidem, f. 1, op. 6, a. e. 245, 1. 6-8; „Narodno Zemedelsko Zname”

11 II 1947; „Pirinsko Delo” 5 V 1947. 
także z interpretowania dziejów macedońskich w duchu antybułgarskim, a to w ówczesnej nowomowie nazywano walką z ,wielkobułgarskim szowinizmem”"33.

Przywiązując wielką wagę do nauczania Macedończyków „piryńskich” języka macedońskiego i zarazem zdając sobie sprawę, że po wprowadzeniu licznych modyfikacji do tego języka władze okręgowe Piryńskiego Kraju nie będą w stanie sprostać kadrowo realizacji tego zadania, liderzy Macedońskiej Partii Komunistycznej zaoferowali swym kolegom partyjnym z Gornej Dżumai przyjazd 25 nauczycieli z LRM do pracy w szkolnictwie w Macedonii Piryńskiej. Propozycja ta została przyjęta przez stronę bułgarską ochoczo i z dużą ulgą. Co więcej, władze okręgu gornodżumajskiego zwróciły się do Ministerstwa Oświaty w Sofii z wnioskiem, aby edukację języka i historii Macedonii uczynić dyscyplinami obligatoryjnymi dla uczniów wszystkich placówek oświatowych w Macedonii Piryńskiej3.

Uległość bułgarskich władz partyjno-rządowych i FO wszelkich szczebli wobec różnorakich żądań i oczekiwań strony jugosłowiańskiej wskazuje na pełne ich podporządkowanie macedonistycznej strategii Belgradu i Skopia, którego przywódcy, z nadania kierownictwa politycznego Komunistycznej Partii Jugosławii (KPJ), realizowali identyczny kurs. Niemniej w ogólnym bilansie dokonań piewcy macedonizmu w Piryńskim Kraju, wywodzący się z najwyższych gremiów KPJ, Macedońskiej Partii Komunistycznej i BPR(k), w zasadzie dysponowali tylko jednym formalnym dowodem macedońskości tego obszaru: rezultatami spisu ludności. Choć, jak wspomniano wyżej, szczegółowa analiza okoliczności, które towarzyszyły tym obliczeniom, rzuca cień na ich wiarygodność, to jednak dla udowodnienia macedonistycznych tez efekty akcji spisowej stanowiły dogodny argument. Stanowiły w odróżnieniu od miernych rezultatów intensywnego wdrażania w Piryńskim Kraju autonomii narodowo-kulturalnej, począwszy od uchwalenia, pod presją Moskwy i Belgradu, słynnej rezolucji X Plenum KC BPR(k), dotyczącej stanowiska najwyższych władz partyjno-państwowych w kwestii macedońskiej.

\section{Bibliografia}

Źródła pierwotne

Centralen D"ržaven Arhiv (CDA):

f. 1 b, op. 5, a.e. $6,1.131-137$;

f. 1 b, op. 5 , a.e. $7,1.1-2$;

f. 28 , op. 1 , a.e. $81,1.168-176$; a.e. $117,1.18-19$;

f. 108 , op. 1, a.e. $6,1.59-61$;

Centralen Partien Arhiv (CPA):

f. 1 , op. 6 , a.e. 245,1 . 6 ; op. 15 , a.e. $221,1.1-7$

f. 4 , op. $1148,1.1-2$

f. 146 , op. 5 , a.e. 24 , 1. 8-23, 18,298

f. 147 , op. 1 , a.e. $1004,1.75-78$; op.3, a.e. 954 , 1. 1; a.e.

f. 214 , op. 1 , a.e. $462,1.1-6$

${ }^{33}$ CPA, f. 1, op. 6, a. e. 245, 1. 6; por. N. Veljanovski, op. cit., s. 185.

${ }^{34}$ CPA, f. 146, op. 5, a. e. 298, 1. 7-9; ibidem, f. 1, op. 6, a. e. 245, 1. 6-8; D. Mitrev, Pirin Makedonia, Skopje b.r.w. s. 68 . 
Okr"žen D"ržaven Arhiv - Blagoevgrad (ODA):

f. 108 , op. 1, a.e. $14,1.423-443$;

f. 58 , op. 1 , a.e. $11,31,47$;

f. 61 , op. 1 , a.e. $36,1.192-193$;

f. 59 , op.1, a.e. $25,1.89 \mathrm{i} \mathrm{nn.}$

Okr"žen Partien Arhiv - Blagoevgrad (OPA):

f. 7 , op.1, a.e. 2 , 1. 118,119 ; a.e. 3 , 1. 80-82; a.e. 8 , 1.6

Źródła publikowane

BKP, Komintern"t i Makedonskiât v"pros (1917-1946), Glavno Upravlenie na Arhivite pri Ministerskiâ S"vet na Republika B"lgariâ, t. II, Sofiâ 1999;

Dokumenti za borbata na makedonskiot narod za samostojnost $i$ za nacionalna država, t. I, Skopje 1981

Makedonskiât v"pros v b"lgaro- ûgoslavskite otnošeniâ (1944-1952), Glavno Upravlenie na Arhivite pri Ministerskiâ S'vet na Republika B"'lgariâ (MVBÛ), Sofiâ 2004, s. 81-82, 94-95

Stenografski dnevnici na Velikoto Narodno S'branie, č I, 1946-1949, 10 zasedanie, Sofiâ 1946

Monografie

V. Angelov, Hronika za edno nacjonalno predatelstvo. Opitite za nasilstveno denacionalizirane na Pirinska Makedoniâ (1944-1949), Blagoevgrad 1999;

N. Davies, Europa. Rozprawa historyka z historia, Kraków 1998;

V. Jotevski, Nacionalnata afirmacja na Macedoncite vo Pirinskot del na Makedonija 1944-1948, Skopje 1996;

E. Kofos, Nationalism and Communism in Macedonia, Thessaloniki 1964;

D. Mičev, Makedonskiât v"pros i b"lgaro-ûgoslavskite otnošeniâ (9 IX 1944-1949), Sofiâ 1994;

D. Mitrev, Pirin Makedonia, Skopje, b.r.w.

L. Panajotov, K. Palešutski, D. Mičev, Makedonskiât v"pros i b"lgaro-ûgoslavskite otnošeniâ, Sofiâ 1987;

H. Poulton, Who are the Macedonians?, Bloomington and Indianapolis 1995;

N. Veljanovski, Makedonija vo jugoslovensko-bugarskite odnosi (1944-1953), Skopje 1998

R. L. Wolff, The Balkans in our Time, Cambridge, Mass. 1956;

E. Znamierowska-Rakk, Federacja Stowian poludniowych w polityce Bułgarii po II wojnie światowej. Korzenie. Próby realizacji. Upadek, Warszawa 2005.

Artykuły w pracach zbiorowych i czasopismach naukowych

V. Angelov, Akcâta za demografsko prebroâvane na naselenie v Pirinskiâ Kraj (25-31 dekemvri 1946 g.), „Istoričeski Pregled” [Sofiâ] 1990, br. 8;

G. V. Dimitrov, Za taka narečenata ,kulturna avtonomiâ" v Blagoevgradski okr "g (1946-1948), „Istoričeski Pregled”, [Sofiâ] 1979, br. 6;

B. Dziewiałtowski-Gintowt, Język jako argument w dyskusji wokót kwestii macedońskiej w XX wieku, [w:] Miejsce Macedonii na Bałkanach, red. I. Stawowy-Kawka, Kraków 2005;

B. Koneski, The Macedonian Language, [w:] The Socialist Republic of Macedonia, Skopje 1974;

E. Znamierowska-Rakk, Działalność egzarchatu bułgarskiego na polu formowania świadomości narodowej Stowian macedońskich u schyłku niewoli osmańskiej, [w:] Tożsamość narodowa w spoteczeństwie multietnicznym Macedonii, red. M. Kawka, I. Stawowy-Kawka, Kraków 2008;

E. Znamierowska-Rakk, Rola duchowieństwa bułgarskiego w rozwoju oświaty na ziemiach macedońskich na przełomie XIX i XX wieku, [w:] Religia a polityka w Europie Środkowo-Wschodniej, red. I. Czamańska, W. Szulc, Poznań 2010; 
E. Znamierowska-Rakk, WMRO i NKMO na przetomie XIX i XX wieku. Sojusznicy czy rywale?, [w:] Macedoński dyskurs niepodległościowy. Historia-Kultura-Literatura-Język-Media, red. I. Stawowy-Kawka, M. Kawka, Kraków 2010.

Prasa

„Demokraciâ" 1990

„Makedonsko Zname” 1947

„Narodno Zemedelsko Zname” 1946, 1947

„Pirinsko Delo" 1947

„Svoboden Narod” 1946

„Zname” 1946

„Zora” 1990

Elżbieta Znamierowska-Rakk

\title{
Bulgarians or Macedonians? Around the National Census in Pirin, Macedonia in December 1946
}

\begin{abstract}
Summary
The report puts forth a thesis about the falsification of the national census in Pirin, Macedonia in December 1946. The results of the census formally announces a Macedonian ethnic face of this territory. The report bases justifying the falsity results of the census on many Bulgarian archival documents of this period. They show a great manipulation in the question of national identification of population in the Pirin Region, in which the majority de facto unambiguously regarded themselves as Bulgarians. The census was carried out under strong pressure of political factors: Soviet Union, Yugoslavia and Bulgarian communist authorities.
\end{abstract}

Keywords: Pirin Macedonia, People's Republic of Macedonia, Moscow, Beograd, Skopje, Sofia, national-cultural autonomy in the Pirin Region, national census in Pirin, Macedonia in December 1946. 